\title{
Correlation Between Interleukin-6 Serum and Hepcidin Serum in Obese Children
}

\author{
Ni Komang Diah Saputri*, I Gusti Lanang Sidiartha, I Made Gede Dwi Lingga Utama
}

Department of Child Health, Udayana University School of Medicine, Sanglah Hospital, Denpasar, Indonesia

Email address:

diah_saputri1987@yahoo.com (Ni K. D. Saputri), lanangsidiartha@yahoo.com (I G. L. Sidiartha),

dwi_lingga09@yahoo.com (I M. G. D. L. Utama)

${ }^{*}$ Corresponding author

\section{To cite this article:}

Ni Komang Diah Saputri, I Gusti Lanang Sidiartha, I Made Gede Dwi Lingga Utama. Correlation Between Interleukin-6 Serum and Hepcidin Serum in Obese Children. American Journal of Pediatrics. Vol. 6, No. 1, 2020, pp. 27-30. doi: 10.11648/j.ajp.20200601.14

Received: January 17, 2020; Accepted: February 6, 2020; Published: February 18, 2020

\begin{abstract}
The number of obesity in children and adolescents is increasing. Obese children are believed to experience chronic inflammation as evidenced by high levels of inflammatory markers, especially interleukin-6 (IL-6). Obese children have high incidence of anemia caused by inflammatory process proven by high level of serum hepcidin. This study aimed to investigate correlation between interleukin 6 with serum hepcidin in obese children, aged 6-10 years old whom were recruited consecutively from elementary schools in Denpasar from November 2016 until April 2017. Obesity was established using the Body Mass Index (BMI) measurements based on the CDC 2000 chart. The correlation between serum IL-6 and serum hepcidin was tested by using pearson test. Fifty-eight subjects in this study had mean Body Mass Index (BMI) $27.3 \mathrm{~kg} / \mathrm{m}^{2}$. The mean interleukin-6 level was $3.1 \mathrm{gr}$ with standard deviation (SD) 2.9 gr. Mean level of serum hepcidin $20.5 \mathrm{ng} / \mathrm{ml}$, standard deviation (SD) $12.5 \mathrm{ng} / \mathrm{ml}$. Pearson's analysis test showed strong positive correlation between IL-6 level and hepcidin serum level $(\mathrm{r}=0.748 ; \mathrm{p}=0.0001)$. Multivariate analysis by using partial analysis showed hepcidin correlate with IL-6 serum and BMI $(\mathrm{r}=0.737$ and $\mathrm{p}=<0.001 ; \mathrm{r}=0.385$ and $\mathrm{p}=0.004$, respectively). Bivariate analysis with matrix correlation showed weak correlation between IL- 6 serum and BMI ( $\mathrm{p}=0.289 ; \mathrm{r}=0.028)$. This study found that IL- 6 serum had strong positive correlation with hepcidin serum in obese children.
\end{abstract}

Keywords: Interleukin-6, Hepcidin, Obese, Children

\section{Introduction}

Nowadays, the prevalence of obesity in children is increasing both in developed or developing country. Obesity is linked to chronic inflammatory condition that is proven by interluekin-6 (IL-6) increment. In obese children, the incidence of anemia is higher compared to those lean children, this anemic condition may relate to inflammation that is proven by increasing hepcidin level, which is known as anemia of chronic disease or anemia of inflammation. Furthermore, this condition raise question whether there will be any correlation between IL-6 and hepcidin.

Obesity increases rapidly in recent years. Data from Riset Kesehatan Dasar (Riskesdas) showed that the prevalence for obesity reached to $9.2 \%$ among school-age children (6-12 years old) in 2010 [1]. While in Denpasar obese children increased from $11 \%$ in 2002 to $21 \%$ in 2013 [2, 3]. The problem of iron metabolism with or without anemia in obese children is quiet high, in several country, with prevalence about $26 \%-45 \%[4,5]$.

Obesity has lot of comorbidities such as diabetes mellitus and hypertension [4], coronary heart disease and stroke [5, 6]. Inflammation plays important role in the process of this comorbid conditions. Adipocytes in obese patient caused molecular changes and intracellular stress which leads to activation of inflammatory cascades [5-7].

Obesity-induced inflammatory responses that is characterized by elevation of inflammatory cytokines and acute phase proteins, such as C-reactive protein (CRP), IL-6, recruitment and activation of leukocyte, regeneration and tissue repair responses [5, 7]. Increase of inflammatory markers indicates the process of chronic inflammation differ with inflammatory infection which is acute process [10]. Interleukin-6 is major cytokine in obese subject include 
children $[5,7]$. This cytokine is found widely and about $30 \%$ of it was produced in adipose tissue. Studies showed IL-6 was higher in obese children. Interleukin-6 is related with hepcidin synthesis during inflammation period that has significant relationship with iron regulation [7, 8].

Hepcidin has vital role in body iron regulator, in addition hepcidin also act as acute-phase reactant which excretion was stimulated by inflammatory mediators or infection. Hepcidin may also play role in iron absorption and excrete iron from macrophage and hepatocyte [9-11].

Inflammation plays major role in obesity. About $90 \%$ of interleukin- 6 is produced by visceral adipose tissue. The greater the BMI define the fat mass which increases the production of IL- 6 then ultimately stimulates hepcidin from liver. Thus the increment of hepcidin serum will interfere the regulation of body iron $[8,9]$.

Hipoferremia condition or decrease of iron status may also happened in obese children, related to chronic inflammatory process that may happened, especially those that may involved IL-6 and hepcidin. Hipoferremia is important, as it may have significant relation with decrease of physical ability, cognitive function, growth and development. The aim of this study was to prove a correlation between IL-6 and hepcidin in obese children $[12,13]$.

\section{Materials and Method}

This was analytical study with cross-sectional design to compare IL-6 and hepcidin in children aged 6-10 years old from November 2016 to April 2017. Samples were taken consecutively based on inclusion and exclusion criteria. The minimum sample was 48 subjects. The inclusion criteria for this study were obese children aged 6 to 10 years old whose parents / guardians agreed and signed informed consent. The exclusion criteria for this study were liver function disorders, impaired renal function, blood disorders, malignancy and chronic infections. History taking, physical examination, height and body weight measurements, blood sampling were performed to all subjects.

Obesity was determined by calculating the body mass index (BMI), divided the weight in kilograms with height in meters squared, then compared to reference values in accordance to age and gender, then plotted on the IMT curve based on gender and age in CDC curve 2000 which showed percentile above 95. Body weight (measured in $\mathrm{kg}$ ) on standing scale, with subject being in a state of minimal clothing, without wearing shoes. Body height (measured in $\mathrm{cm}$ ) was measured using plastic rulers attached to the wall, with subjects standing upright, back against the wall, without wearing shoes. Body mass index (BMI) was defined as body weight divided by body height squared $\left(\mathrm{kg} / \mathrm{m}^{2}\right)$.

IL-6 level was measured by using the quantitative enzyme immuno-assay sandwich technique. Hepcidin was measured by ELISA system with Hepsidin-25 ELISA kit. Serum IL-6 and hepcidin level were examined simultaneously by using syringe in the medial cubital vein.

Data was processed by computer program as descriptive analysis for the basic characteristic of nominal and numeric scale, which results were presented in tabular and narrative with $95 \%$ confidence interval. Normality test was performed by using Kolmogorov-Smirnoff and showed normal result. Linearity test was performed by using scatter graphic. The correlation analysis was performed by Pearson test, which would significant if $p<0.05$. Multivariate analysis was performed with partial correlation analysis by using age, gender and BMI as control variables. This study had been approved by Research Ethics Committee of Udayana Medical School, Sanglah Hospital, Denpasar

\section{Results}

Socialization was conducted on several primary school in Denpasar, we found 130 obese children, 62 children declined from study, 4 children were excluded because their age more than 11 years old and 6 children were excluded because of liver malfunction. During the study period, there were 58 samples who fulfilled the inclusion criteria.

In this study, 58 subjects with 31 subjects (53.4\%) were male. With description of subject's characteristics can be seen in Table 1.

Table 1. Subjects' characteristics.

\begin{tabular}{ll}
\hline Characteristics & Total $(\mathbf{n = 5 8})$ \\
\hline Gender, Male (\%) & $31(53.4)$ \\
Mean age (SD) & $9.6(1.0)$ \\
Mean BMI (SD) & $27.3(3.2)$ \\
Mean height (SD) & $139.7(7.8)$ \\
Mean weight (SD) & $52.6(10.0)$ \\
Interleukin-6 (pg/dl), mean (SD) & $3.1(2.9)$ \\
Hepcidin (nmol/l), mean (SD) & $20.5(12.5)$ \\
\hline
\end{tabular}

The correlation between IL- 6 and hepcidin showed a significant positive correlation $(r=0.748: p<0.001)$, see Figure 1.

Multivariate analysis was conducted to determine the correlation between serum hepcidin and IL-6 with other factors such as age, gender and BMI performed by using partial correlation analysis (Table 2).

Table 2. Multivariate analysis results.

\begin{tabular}{lll}
\hline Variables & r partial & p \\
\hline IL-6 $(\mathrm{pg} / \mathrm{dL})$ & 0.737 & $<0.001$ \\
Age $($ years old $)$ & -0.088 & 0.521 \\
Gender & 0.212 & 0.121 \\
BMI $\left(\mathrm{kg} / \mathrm{m}^{2}\right)$ & 0.385 & 0.004 \\
$\mathrm{r}$ multivariate $=0.798$ & & \\
$\mathrm{r}^{2}$ multivariate $=0.637$ & & \\
\hline
\end{tabular}

In this study, bivariate test was elaborated further by matrix of correlation between IL-6, age, gender and BMI to determine the effect of those variables (Table 3 ). 


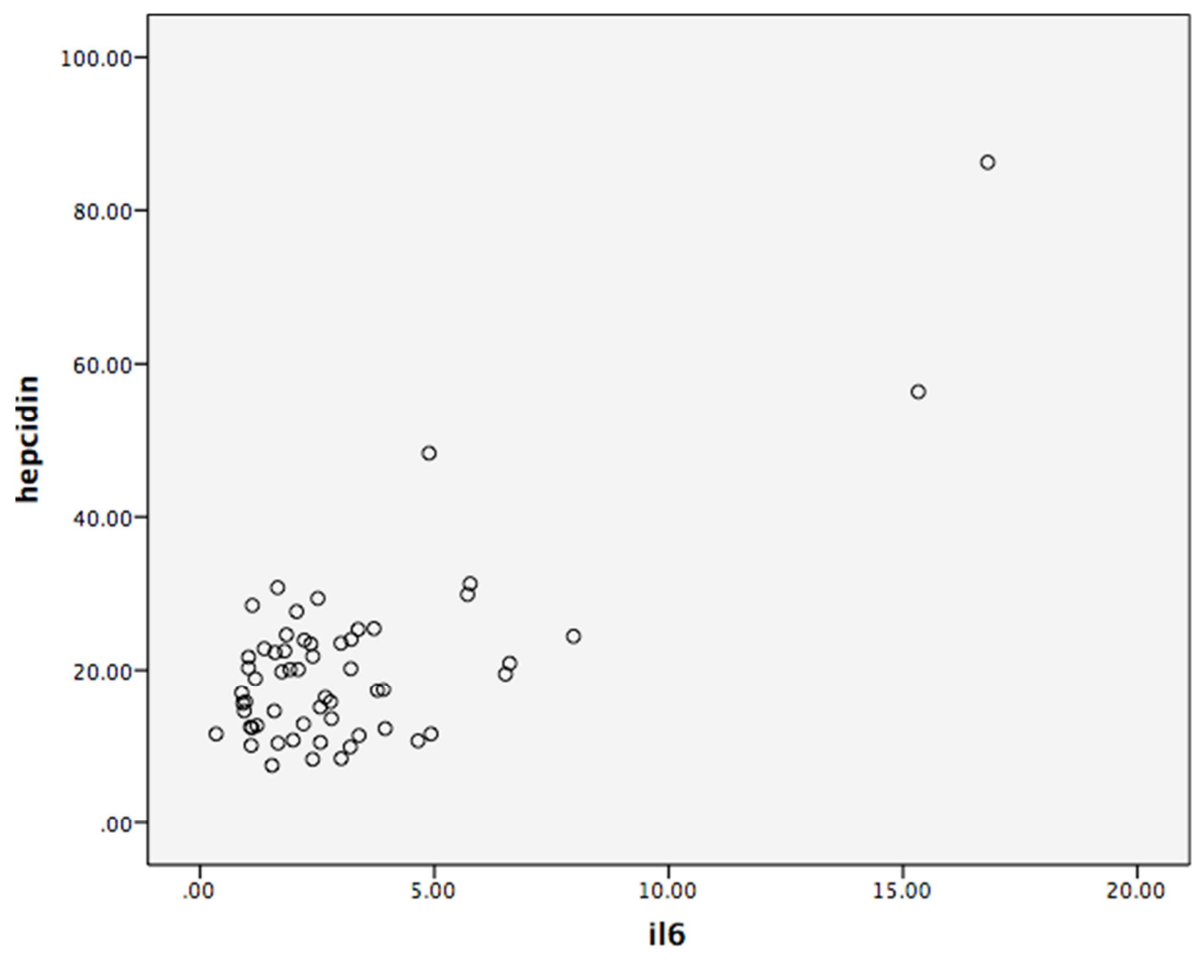

Figure 1. Correlation between level of interleukin-6 and hepcidin.

Table 3. Matrix of correlation.

\begin{tabular}{llll}
\hline Variables & IL-6 (pg/d) & BMI $\left(\mathbf{k g} / \mathbf{m}^{2}\right)$ & $\begin{array}{l}\text { Age (years } \\
\text { old) }\end{array}$ \\
\hline BMI $\left(\mathrm{kg} / \mathrm{m}^{2}\right)$ & $\mathrm{r}=0.289$ & & \\
& $\mathrm{p}=0.028$ & & \\
Age (years old) & $\mathrm{r}=-0.014$ & $\mathrm{r}=0.017$ & \\
& $\mathrm{p}=0.917$ & $\mathrm{p}=0.898$ & \\
Gender & $\mathrm{r}=-0.191$ & $\mathrm{r}=-0.117$ & $\mathrm{r}=0.133$ \\
& $\mathrm{p}=0.151$ & $\mathrm{p}=0.382$ & $\mathrm{p}=0.321$ \\
\hline
\end{tabular}

\section{Discussion}

Obesity is a serious health condition, associated with many comorbidities either in children or adult. In obesity, the body develops chronic low grade inflammation that may interfere ferrous metabolism which will decrease serum iron and developing anemia that is known as anemia of chronic disease or anemia of inflammation [12].

Total 58 obese children aged 6 to 10 years old were analyzed in this study. The anthropometric data includes weight, height, and body mass index. Blood samples were taken for measurement serum level of IL-6 and hepcidin. From this research we got 31 (53.4\%) male and 27 (46.6\%) female children. During this time period, children are risky for obesity as there will be increase of nutrition intake [13].

The mean level of IL- 6 in obese children in this study was $3.1 \mathrm{ng} / \mathrm{ml}$ which was higher than the mean value of IL-6 in normal children $(1.07 \pm 0.41 \mathrm{pg} / \mathrm{mL})$. The previous study found that IL- 6 obese children were ten times higher than in normal-weight children which was statistically significant different $(\mathrm{p}<0.05)$.

In this research the mean level of hepcidin was $20.5 \pm 12.5$ $\mathrm{nmol} / \mathrm{l}$, that was in accordance with other research. This level was higher than mean level of hepcidin in lean child $(16.71 \pm 14.74 \mathrm{nmol} / \mathrm{l})$. The mean level of hepcidin in this research was not very different with previous research $(20.2 \pm 5,69 \mathrm{nmol} / \mathrm{l})$ [14]. The increase of hepcidin level in obese kids was related with the increment of hepcidin stimulation caused by on-going chronic inflammation. Hepcidin is not just produced by liver but also by adipose tissue in small number. Hepcidin was not the only iron regulator but also act as acute phase reactant $[6,15]$.

Based on Pearson test, there was a positive correlation between IL-6 dan hepcidin, the correlation was strong and statistically significant $(\mathrm{r}=0.748 ; \mathrm{p}<0.001)$. This proved an increment or decrement of IL- 6 will be followed by an increment and decrement of serum hepcidin. This result was in accordance with author's hypothesis. The authors suspect a correlation between IL-6 serum and hepcidin level in obese children. This can happen, as described in literature. In obese children, there are chronic inflammation that may induce secretion of proinflammatory cytokine especially IL-6 that may induce the expression of gene transcription of hepcidin in hepatocyte cells $[9,11]$.

Multivariate analysis showed that IL-6 has strong correlation with serum hepcidin ( $\mathrm{r}$ partial $=0.737$; $\mathrm{p}<0.001$ ). This results showed chronic inflammation that happened in obesity may play important role in the increment of hepcidin level [8, 18]. We also found a weak positive correlation between BMI with hepcidin level $(\mathrm{r}=0.385$; $\mathrm{p}=0.004)$. Previous research showed positive correlation between BMI and serum hepcidin level, the larger the BMI, the higher the hepcidin level of the patients $(\mathrm{p}<0.002 ; \mathrm{r}=+0.95)$ [16].

Bivariate analysis showed matrix of positive correlation in IL-6 and its relationship with BMI $(r=0.289 ; \mathrm{p}=0.028)$. 
Previous research in children showed a moderate correlation $(\mathrm{r}=0.418 ; \mathrm{p}=0.009)[17]$. About $90 \%$ of interleukin-6 is produced by visceral adipose tissue, which has been proven in a study in Bali that showed significant relationship between waist circumference and IL-6 in obese adult [19]. It's fit with the basic concept that inflammation plays major role in obesity, which empower the link between BMI and IL-6, the greater the BMI the greater the fat mass that will increase the production of IL- 6 and ultimately stimulates hepcidin production in liver. The increment of those hepcidin serum can interfere the regulation of body iron $[8,20,21]$.

\section{Conclusion}

Interleukin-6 level had strong positive correlation with hepcidin levels and this correlation was statistically significant.

\section{Funding}

The authors received no financial support for the research, authorship, and/or publication of this article.

\section{References}

[1] Riskesdas. 2010. Laporan Nasional 2013. Badan Penelitian dan Pengembangan Kesehatan Kementerian Kesehatan Republik Indonesia. h. 204-20.

[2] Gary, A., Soetjiningsih. Prevalence and risk factors of overweight and obesity in adolescents. Paediatr Indones. 2002; 42: 206-11.

[3] Ratna, M. D., Sidiartha, I. G. L. Prevalensi dan faktor risiko obesitas anak sekolah dasar di daerah urban dan rural. Medicin. 2013; 44: 15-21.

[4] Cardoso, M. A., Scope, K. K. G., Muniz, P. T., Villamor, E., Ferreira, M. U. Underlying factors associated with anemia in Amazonian children: A population-based, cross-sectional study. Plus One. 2012; 7 (5): 1-8.

[5] Shamah-Levy, T., Villalpando, S., Jauregui, A., Rivera, J. A. Overview of the nutritional status of selected micronutrients in Mexican children in 2006. Salad Publica de Mexico. 2012. 54 (2): 146-51.

[6] Arslan, N., Erdue, B., Aydin, A. Hormones and cytokines in childhood obesity. Indian Pediatr. 2010; 47: 829-39.

[7] Schwarzenberg, S. J., Sinaiko, A. R. Obesity and inflammation in children. Paediatr Respir Rev. 2006; 7: 23946.
[8] Rocha, V. Z., Folco, E. J. Inflammatory concepts of obesity. Int J inflame. 2011; 20: 11-8.

[9] Kwapisz, J., Artur, S., Ewa, Z. Hepcidin and its role in iron homeostasis. EJIFCC. 2009; 20: 124-8.

[10] McClung, J. P, Karl, J. P. Iron deficiency and obesity: the contribution of inflamation and diminished iron absorption. Nutrition Reviews. 2009; 67: 100-4.

[11] Ganz, T., Nemeth, E. Hepcidin and Iron Homeostasis. Biochimica et Biophysica Acta. 2012; 1823: 1434-43.

[12] Baker, R. D., Greer, R. R. Diagnosis and prevention of iron deficiency and iron deficiency anemia in infants and young children (0-3 years of age). Pediatrics. 2010; 126; 1040-50.

[13] Rolland-Cachera, M. F., Deheeger, M., Maillot, M., Bellisle, F. Early adiposity rebond: causes and consequencies for obesity in children and adults. International Journal of Obesity. 2006; 30: S11-S17.

[14] Ridha, N. R., Daud, D. Hubungan kadar hepcidin dengan status besi pada inflamasi akibat obesitas. Sari pediatric. 2014; 16: $161-6$.

[15] Żekanowska, E. Boinska, J. Giemza-Kucharska, P. Kwapisz, J. Obesity and low-grade inflamation: a paediatric perspective. J Biotechnol. 2011; 92: 147-152.

[16] Hamza, R. T., Hamed, A. I., Kharshoum, R. R.. Iron homeostasis and serum hepcidin-25 levels in obese children and adolescents: relation to body mass indeks. Horm Res Paediatr. 2013; 80: 11-7.

[17] De Filippo, G., Rendina, D., Moccia, F., Rocco, V., Campanozzi, A. Interleukin 6, soluble interleukin 6 receptor/interleukin 6 complex and insulin resistance in obese children and adolescents. J Endocrinol Invest. 2015; 38 (3): 339-43.

[18] Sánchez, A. F., Santillán, E. M., Bautista, M., Soto, J. E., González, A. M., Chirino, C. E. Inflammation, oxidative stress and obesity. Int J Mol Sci. 2011; 12: 3117-32.

[19] Gotera, W., Mahadita, W., Bakta, I. M., Oka, A. A. G., Budiartha, A. A. G., Manuaba, P., Maliawan, S. Waist circumference increased risk of benign prostatic hyperplasia through an increase in the level of interleukin- 6 and insulin resistance in abdominal obesity patients. Bali Med J. 2017; 6 (1): 2014-20.

[20] Greenberg, A. S., Obin, M. S. Obesity and the role of adipose tissue in inflammation and metabolism. Am J Clin Nutr. 2006; 83: 461S-5S.

[21] Eder, K., Baffy, N., Falus, A. The major inflammatory mediator interleukin-6 and obesity. Inflamm. Res. 2009; 58: 727-36. 